EDUKACJA MIĘDZYKULTUROWA

2015, nr 4

ISSN 2299-4106

MirosŁawa Pindór

\title{
Przestrzeń współbycia. Těšínské niebo Cieszyńskie nebe Těšínského divadla w Českém Těšíně jako międzykulturowa narracja o wielokulturowości miasta/miast
}

Streszczenie: W artykule poddano analizie dwujęzyczny dramaturgiczno-inscenizacyjny wspólny projekt Sceny Polskiej i České scény (Sceny Czeskiej) Těšínského divadla (Teatru Cieszyńskiego) w Českém Těšíně (Czeskim Cieszynie) pn. Těšínské niebo Cieszyńskie nebe. Ten muzyczny „sentymentalny rajd tramwajowy - sentymentální tramvajová rallye" przez wieki po wielokulturowym regionie i wielokulturowym mieście był - zgodnie z zamierzeniem realizatorów przedsięwzięcia: Jaromíra Nohavicy, Renaty Putzlacher, Radovana Lipusa, Tomaša Kočko - „próbą spojrzenia na cieszyńską ziemię przez pryzmat minionych lat i zdarzeń, pełną nostalgii i humoru, z przywołaniem związanych z tym regionem postaci prawdziwych i mitycznych"1. Próbą przeprowadzoną zgodnie z przyjętą przez autorów projektu nadrzędną, zainspirowaną przez ideę euroregionu, zasadą eksponowania tego, co społeczność pogranicza łączyło/łączy i w efekcie tworzy płaszczyznę wartości wspólnych, a nie tego, co dzieliło/dzieli. Poszukiwanie wspólnych elementów kultury, podobieństw dziejów okazało się tutaj zbieżne z założeniami edukacji międzykulturowej. Przyjętą opcję postrzegania polsko-czeskich pogranicznych dziejów oraz wizję współistnienia obu narodów w Cieszyńskim determinował nadto fakt przyjęcia obu państw w struktury Unii Europejskiej (premiera spektaklu 15 maja 2004 roku). Z tej perspektywy została skonstruowana materia następujących po sobie sekwencji spektaklu i wyłaniała się koncepcja człowieka pogranicza jako człowieka pełniejszego, bo wzbogaconego duchowo innością drugiego. Przedstawienie współuczestniczyło w podejmowanym po 1989 roku procesie formowania odpowiednio wysokiego poziomu zbiorowej tożsamości lokalnej, regionalnej oraz euroregionalnej społeczności zamieszkujących oba miasta graniczne i oba przygraniczne obszary.

Słowa kluczowe: pogranicze, Cieszyn - Český Těšín, wielokulturowość, międzykulturowość, tożsamość, teatr, Těšínské divadlo

1 Zob. I. Heclová, A. Jarnotová, J. Wania (red.): Nabídka představení Těšinského divadla v Českém Těšínè. Sezona 2003/2004. Repertuar Sceny Polskiej Teatru Cieszyńskiego w sezonie 2003/2004. Český Těšín 2003. 
Wieloaspektowy dialog międzykulturowy na pograniczu polsko-czeskim w Cieszyńskiem realizowany jest również w wymiarze teatralnym² ${ }^{2}$. Niniejszy szkic ogranicza się do jednej tylko inicjatywy z zakresu sztuki teatru, na tyle jednak społecznie, kulturowo ważnej i nośnej, że wartej osobnego przywołania i przeanalizowania.

U progu sezonu teatralnego 2003/2004 troje artystów miejscem urodzenia, wzrastania bądź zamieszkania związanych z czeską częścią Śląska Cieszyńskiego: czeski pieśniarz, poeta i kompozytor Jaromír Nohavica, polska poetka i tłumaczka Renata Putzlacher, czeski reżyser Radovan Lipus powzięło zamiar spożytkowania potencjału artystycznego i językowego Těšínského divadla (Teatru Cieszyńskiego) w Českém Těšíně (Czeskim Cieszynie) - teatru dwóch scen dramatycznych: czesko- i polskojęzycznej3, gdzie zgodne relacje między kulturami narodowymi są kwestią powszednią oraz potencjał społeczno-kulturowy pogranicza polsko-czeskiego w Cieszyńskiem, którego przywołana unikatowa, nawet w skali Europy, teatralna dwoistość jest nader cennym wytworem. Wspólny namysł trojga dwujęzycznych twórców, do któ-

2 Na temat dialogu teatralnych kultur - polskiej, czeskiej i słowackiej zob.: M. Pindór: Polsko-czeskie i polsko-stowackie kontakty teatralne. Cieszyn - Český Tešín 1945-1999. Katowice 2006, Polska Akademia Nauk Oddział w Katowicach, Komisja ds. Stosunków Polsko-Czeskich i Polsko-Słowackich, Wydawnictwo Naukowe i Artystyczne „Gnome”. Taż: Od przestrzeni absurdu do przestrzeni wolności. XX lat Międzynarodowego Festiwalu Teatralnego „na granicy” „bez granic”. W: M. Kaute, J. Okrzesik (red.): Obywatele dyplomaci. Solidarność Polsko-Czesko-Stowacka w Cieszynie i Bielsku-Białej. Bielsko-Biała 2009, Wydawnictwo Wyższej Szkoły Bankowości i Finansów w Bielsku-Białej, s. 73-84.

3 Teatr w Czeskim Cieszynie - założony dzięki inicjatywie miejscowych entuzjastów Melpomeny - rozpoczął swą działalność 25 września 1945 roku, jako Těšínské oblastní divadlo (Cieszyński Teatr Regionalny). Swoją pierwszą premierę - Noc na Karlsztejnie Jaroslava Vrchlickiego dał 6 października. Nazewnictwo teatru ulegało zmianie jeszcze dwukrotnie: w latach 1946-1948 powszechnie obowiązująca była nazwa Divadlo Těšínského Slezska (Teatr Śląska Cieszyńskiego), od lipca 1948 roku do dziś - Těšínské divadlo (Teatr Cieszyński). Od sierpnia 1951 roku jest to teatr dwóch scen: České scény (Sceny Czeskiej) i Sceny Polskiej, która zainaugurowała swą działalność 14 października 1951 roku premierą sztuki Aleksandra Maliszewskiego Wczoraj i przedwczoraj. Od sezonu 2008/2009 trzecim zespołem Těšínského divadla jest Scena Bajka - teatr lalkowy. Wymienione, w pełni profesjonalne zespoły teatralne działaja pod jednym dachem (od 1961 roku w nowoczesnym budynku przy ul. Ostrawskiej) i pod jedną dyrekcją (od 2000 roku Karola Suszki) oraz samodzielnym kierownictwem artystycznym i samodzielnym kierownictwem literackim. 
rych z czasem dołączył czeski muzyk Tomaš Kočko, ich serdeczne pochylenie się nad ziemią cieszyńską - jej historią i współczesnością, z uwzględnieniem specyfiki stosunków polsko-czeskich i czesko-polskich na przestrzeni dziejów, a nade wszystko myślenie o macierzystym regionie, a przede wszystkim o obu miastach granicznych: Cieszynie i Českém Těšíně, jako o wielokulturowej przestrzeni wspólnej, przestrzeni współbycia różnych nacji ${ }^{4}$, poddawanej procesowi międzykulturowej dialogizacji, skutkowało przygotowaniem dramaturgiczno-inscenizacyjnego dwujęzycznego (de facto wielojęzycznego $)^{5}$ wspólnego projektu Sceny Polskiej i Sceny Czeskiej Td pn. Těšínské niebo Cieszyńskie nebe $e^{6}$, bazującego na pieśniach Jaromíra Nohavicy, przetłumaczonych przez R. Putzlacher.

Ten muzyczny „sentymentalny rajd tramwajowy - sentymentální tramvajová rallye" (jak czytamy w podtytule projektu) przez wieki po wielokulturowym regionie i wielokulturowym mieście miał być - w zamierzeniu realizatorów przedsięwzięcia - „próbą spojrzenia na naszą [cieszyńską M.P.] ziemię przez pryzmat minionych lat i zdarzeń, pełną nostalgii i humoru, z przywołaniem związanych $\mathrm{z}$ tym regionem postaci prawdziwych i mitycznych"7. Próbą, dodajmy, przeprowadzoną zgodnie z przyjętą przez autorów projektu nadrzędną, niewątpliwie zainspirowaną przez ideę euroregionu, zasadą eksponowania tego, co społeczność pogranicza łączyło/łączy i - w efekcie - tworzy płaszczyznę wartości wspólnych, a nie tego, co dzieliło/dzieli. Poszukiwanie „wspólnych elementów kultury, podobieństw dziejów i doświadczeń"8 okazało się tutaj zbieżne z założeniami edukacji mię-

4 Determinantem wielonarodowościowego, wielokulturowego profilu Śląska Cieszyńskiego była i jest zmienność formacji państwowych, dotykająca tego obszaru historycznego Śląska, zwłaszcza położonego za rzeką Olzą.

5 W spektaklu wybrzmiewają języki wiodących nacji zamieszkujących dawny Śląsk Cieszyński, mianowicie: polski, czeski, niemiecki, jidysz, nadto zgodnie z rytmem dziejów Śląska Cieszyńskiego pojawia się słownictwo rosyjskie, angielskie, francuskie.

6 Wspólne projekty teatralne obydwu scen Td zdarzały sie już w przeszłości. Miały one jednak charakter sporadyczny. Szerzej na ten temat zob. M. Pindór: Polsko-czeskie i polsko-stowackie kontakty teatralne. Cieszyn - Český Těšin 1945-1999. cyt. wyd., s. $139-141$.

7 Zob. I. Heclová, A. Jarnotová, J. Wania (red.): Nabídka představení Těšínského divadla v Českém Těšinè. Sezona 2003/2004. Repertuar Sceny Polskiej Teatru Cieszyńskiego w sezonie 2003/2004. cyt. wyd.

8 Lewowicki T.: W poszukiwaniu modelu edukacji międzykulturowej. W: T. Lewowicki, J. Nikitorowicz, T. Pilch, S. Tomiuk (red.): Edukacja wobec ładu globalnego. 
dzykulturowej. Z tej perspektywy została skonstruowana materia scenariusza i zorganizowana narracja sceniczna, dobrany został tytuł, dowcipnie wiążący obie nacje i oba miasta. Nie wszystkie bowiem daty z niełatwych przecież dziejów polsko-czeskiego sąsiedztwa w Cieszyńskiem zostały w inscenizacji przywołane. Świadomie pominięto fakty „zapalne” z roku 1919 i roku 1938, jako najbardziej antagonizujące oba narody, odmiennie postrzegane, nazywane i interpretowane przez historyków obu narodowości. Dramatyczny dla mieszkańców pogranicza, zwłaszcza dla polskiej społeczności na Zaolziu, sierpień roku 1968 pojawia się sygnalnie tylko wraz z pieśnią Nohavicy Ja$c e k$, ale przecież istotą songu jest de facto „w praktyce demonstrowana solidarność" dwojga opozycjonistów porozumiewających się przez graniczną rzekę Olzę, solidarność autentyczna, nie fasadowa - realizowana w dobie normalizacji przez oficjalne czynniki partyjne w imię zasad internacjonalizmu (opozycję tę zobrazowano, rozbijając strukturę songu wypowiedziami partyjnych dygnitarzy - Edwarda Gierka i Oldřicha Volenika z Ostrawy, dotyczącymi przyjaźni i braterstwa pomiędzy narodami PRL i CSRS). Jeżeli w spektaklu zdarzają się utarczki słowne polsko-czeskie, czesko-polskie, polsko-niemieckie, czesko-niemieckie, mają one charakter wyłącznie towarzyski, poniekąd familiarny, zgoła humorystyczny. Przyjętą na poziomie scenariusza $\mathrm{i}$ konsekwentnie realizowaną $\mathrm{w}$ toku pracy nad spektaklem opcję postrzegania polsko-czeskich pogranicznych dziejów oraz wizję współistnienia obu narodów na pograniczu polsko-czeskim w Cieszyńskiem determinował nadto niewątpliwie fakt rychłego przyjęcia obu sąsiadujących państw w struktury Unii Europejskiej z jej regulacjami prawnymi, wpierającymi różnorodność kulturową ${ }^{9}$, wymuszającymi wśród państw przystępujących do UE „nowe spojrzenie na kwestie wielokulturowości i edukację międzykulturową" ${ }^{10}$ oraz

Warszawa 2002, Wyższa Szkoła Pedagogiczna ZNP, Instytut Pedagogiki Społecznej i Resocjalizacji UW, Wydawnictwo Akademickie „Żak”, s. 26.

9 „Pierwszym elementem wspierania różnorodności kulturowej w Unii Europejskiej jest odwoływanie się do zasad wielokulturowości w tworzeniu społeczeństwa europejskiego [...]. Drugim elementem jest wspieranie wielojęzyczności społeczeństwa [...]. Kolejnym przykładem [...] jest oparcie społeczeństwa europejskiego na »wolnych wspólnotach « (Euroregiony)". E. Pająk: Edukacja międzykulturowa w szkole na przykładzie programu Coverdell World Wise Schools (CWWS) - wyzwania wielokulturowości w Stanach Zjednoczonych i Unii Europejskiej. W: A. Szerląg (red.): Wielokulturowość - międzykulturowość obszarami edukacyjnych odniesień. Kraków 2005, Uniwersytet Wrocławski, Oficyna Wydawnicza „Impuls”, s. 177-178.

10 T. Lewowicki: W poszukiwaniu modelu edukacji międzykulturowej. W: T. Le- 
fakt zniesienia granic, premiera spektaklu miała bowiem miejsce 15 maja 2004 roku i w zamyśle honorowała przystąpienie Polski i Republiki Czeskiej do Unii. Przyjętą opcję unaoczniają słowa pieśni finałowej inscenizacji: „Już otwarte są na oścież bramy/miłosierny czas zabliźnił rany”. Przy czym sam tytuł pieśni: Každý si nese své briímě wydaje się znaczący, wymowny - winy zaistniałe i niekwestionowane (aczkolwiek w materii spektaklu nie przywołane) dzielone są obopólnie; w jednoczącą się Europę mieszkańcy pogranicznego Śląska Cieszyńskiego - Polacy, Czesi wchodzą z własną lokalną historią, za którą każda $\mathrm{z}$ wymienionych nacji ponosi własną odpowiedzialność. Jednocześnie wchodzą zespoleni, zintegrowani, mocni wielokulturowością, bez hierarchizowania i umniejszania wagi dorobku każdej z kultur. Taka wymowa przedstawienia zbieżna jest z głównym celem komunikacji międzykulturowej - budowaniem wspólnej rzeczywistości.

W efekcie z następujących po sobie sekwencji spektaklu wyłaniała się koncepcja człowieka, „dla którego - jak zauważa Krystyna Kardyni-Pelikanová - problem Swój i Obcy nie jest problemem walki, lecz sprawą syntezy w „człowieka pogranicza”, człowieka pełniejszego, bo wzbogaconego duchowo innością tego drugiego [...]. Istotną sprawą jest tutaj nie tyle życie w oblężonej ziemi, nie tyle filozofia ślimaczego przetrwania, ile otwarcie się na wolność wyboru własnego Losu"11. Doskonały przykład tego wzbogacania poprzez proces poznawania Innego i uczenia się „współżycia z owym Innym”12 przynosi już scena pierwsza przedstawienia, gdy dzieci czterech narodowości zamieszkujących Śląsk Cieszyński na przełomie wieków XIX i XX oraz na początku XX wieku: polskiej, czeskiej, niemieckiej i żydowskiej, zjednoczone początkowo wspólną zabawą „w Cieszyn”"13, „edukują się” następnie „ze swoich kultur", komponując wspólnie zadanie domowe poświęcone Cieszynowi.

Spektakl Těšínské niebo Cieszyńskie nebe był zarówno pójściem w konstytuującą tożsamość regionalną historię prawdziwą Śląska Cieszyńskiego, wyselekcjonowaną zgodnie z przyjętą wymową przedstawienia, jak i kreacją artystyczną

wowicki, J. Nikitorowicz, T. Pilch, S. Tomiuk (red.): Edukacja wobec ładu globalnego. cyt. wyd., s. 31.

11 K. Kardyni-Pelikanová: Těšínské niebo - Cieszyńskie nebe, czyli górą bliźnięta (zodiakalne). „Zwrot” 2006, nr 1.

12 Tamże.

13 Zabawa ta organizowana jest wokół pierwszej zwrotki piosenki dziecięcej Mało nas, mało nas do pieczenia chleba, zachęcającej coraz to nowe osoby do współuczestnictwa w niej. 
(wszak był dziełem artystów, nie historyków, i nie do teatru faktu przynależał). Przywołane w toku scenicznej narracji wybrane fakty historyczne, bogate w swej różnorodności zdarzeniowej i tonacji emocjonalnej ${ }^{14}$, jak i fakty kulturowe ${ }^{15}$, współistniały z osobiście poczynionymi przez autorów i wykonawców projektu obserwacjami dotyczącymi współczesnego życia na granicy ${ }^{16}$, przy czym sceniczne wizualizacje życia na granicy (i z granicy) z jednakową dozą sympatii i humoru traktowały obie przygraniczne społeczności - polską i czeską. Opowieści prawdziwe, aczkolwiek nierzadko niecodzienne (np. pojawienie się komety nad Cieszynem), sąsiadowały z powszechnie znanymi podaniami i legendami Śląska Cieszyńskiego ${ }^{17}$. Ten walor poznawczy i edukacyjny inscenizacji jest nie do przecenienia, podnosi wartość rodzimego piśmiennictwa sytuującego się w nurcie cieszyńskiej kultury ludowej. Przytoczono w spektaklu także wiele lokalnych ciekawostek, anegdot do tej pory nieuwzględnianych w obiegowej wersji lokalnej historii. Wprowadzono w tkankę przedstawienia ludowe przysłowia, porzekadła nierzadko powstałe na kanwie stereotypów narodowych ${ }^{18}$, sformułowania poza Cieszyńskiem praktycznie nieznane, a nawet i na rodzimym obszarze stopniowo zapominane.

W jednej przestrzeni na równych prawach współistniały przynależne do różnych narodowości postacie historyczne - osobistości Cieszyn odwiedzające, znakomitości pochodzące ze Śląska Cieszyńskiego, znani z imienia i nazwiska bądź niestandardowych zachowań mieszkańcy wielokulturowego

14 Przykładowo przywołano, wizualizując, bądź poprzestając jedynie na przekazie słownym: wojnę trzydziestoletnią, dżumę w mieście, podpisanie w 1779 roku pokoju cieszyńskiego kończącego wojnę między Prusami i Austrią, podział miasta w 1920 roku z dramatycznym wezwaniem: „skasujmy druty”, migrację do Ameryki „za chlebem", Holocaust, wielką powódź z lat 70. XX wieku.

15 W spektaklu między innymi zaprezentowano cieszyńskie zabytki i nowo powstałe budowle, przedstawiono rozwój lokalnego wielojęzycznego piśmiennictwa. Zainscenizowano wielki bal maskowy, mający miejsce w dniu otwarcia nowego Browaru Miejskiego w 1000-lecie legendarnego założenia Cieszyna, tj. w 1810 roku.

16 Przemyt alkoholu przez granicę, handel pokątny i handel jawny, humorystyczne sytuacje na targowisku miejskim w Cieszynie.

17 Wśród nich między innymi podania o narodzinach ziemi cieszyńskiej z uśmiechu Boga, o kwiecie cieszynianką wiosenną zwanym, o zbójniku Ondraszku, o Złotogłowcu, o utopiach.

18 Na obecność w spektaklu narodowych stereotypów zwróciła uwagę Klara Pergelová. K. Pergelová: Těšinské niebo pod Vyšehradským nebem. http://folktime.cz (24.08.2005). 
Cieszyna, przedstawiciele poszczególnych zawodów i stanów z postaciami mitycznymi. Ogółem przez scenę przewinęło się 50 postaci w wykonaniu 12 aktorów, przy czym jedna z postaci wydaje się piszącej te słowa szczególnie warta przywołania, bo do dwóch kultur jednakowo przynależna, a jest nią Józef Bożek/ Josef Božek - konstruktor pierwszego na gruncie europejskim pojazdu parowego, o którego osobę - z racji talentu i osiągnięć - upominają się zarówno Polacy, jak i Czesi ${ }^{19}$ (w tym przypadku nie ma tutaj zgody). W wypowiedziach przywołane zostało niezaprzeczalne piękno widokowe Śląska Cieszyńskiego (góry Czantoria, Godula, Gańczorka, Ropica, Kozubowa, rzeka Olza), traktowanego jako jedna niepodzielona kraina geograficzna. Sposób istnienia miejsca - miasta, regionu - rozpatrywany był zatem w inscenizacji zgodnie z przyjętą nadrzędną zasadą - w powiązaniu z odpowiadającym mu wspólnotowym doświadczeniem przestrzennym. W tym kontekście w pełni zasadne stawało się wprowadzenie w materię scenariusza i jego scenicznej wizualizacji słów pieśni Płyniesz Olzo po dolinie Jana Kubisza z roku 1889, będącej nieoficjalnym hymnem Śląska Cieszyńskiego (współcześnie przede wszystkim Śląska Zaolziańskiego).

Bogata w treści narracja sceniczna o wielokulturowości miasta nad i za Olzą położonego i regionu całego - zamieszkałego przez stulecia nie tylko przez Polaków, Czechów, Niemców i Żydów, ale także Słowaków, w mniejszym stopniu Węgrów i Romów, z jednoczesnym wskazaniem ich zasług dla miasta i regionu, który to aspekt najlepiej oddaje dialog Ojca z Synem z roku $1910^{20}$ (Syn: Tato, kto to są ci Niemcy [...] co oni tu robią? Dlaczego nie wracają do domu, do siebie? /Ojciec: Oni są u siebie, tak jak my. Cieszyn to taki tygiel narodów. A Niemcy nam go rozbudowali, uprzemysłowili”21 stanowiła dla cytowanej już Krystyny Kardyni-Pelikanovej próbę stworzenia „jasnego mitu”, w którym „wydobywa się cechy dodatnie terenu: piękno, ład, szczęście, przywiązanie do tej ziemi, będącej wielkim skrzyżowaniem histo-

19 Tego genialnego konstruktora, pomimo że urodził się koło Skoczowa, Czesi uznają za „czeskiego wynalazcę", z racji jego wieloletniego zamieszkiwania w Pradze, gdzie powstała większość jego prac (stąd w scenariuszu i spektaklu pojawia się jako Josef Božek).

20 Takie datowanie wiodących sekwencji przedstawienia wydaje się w pełni zasadne. „Lato rok tysiąc dziewięćset dziesięć” pojawia się bowiem w otwierającej spektakl niemalże kultowej pieśni Nohavicy pt. Těšínská, rozpisanej na głosy przedstawicieli czterech nacji podówczas Cieszyn zamieszkujących.

21 Renata Putzlacher, Radovan Lipus: Těšínské niebo Cieszyńskie nebe. Scenariusz, s. 33, archiwum Těšínského divadla, Český Těšín. 
rycznym, wielkimi rozstajami, na których odbywa się ustawiczny dialog kultur"22. Podobnie interpretował Těšínské niebo - Cieszyńskie niebo Sławomir Wójcik: „artyści tworzą wizję Cieszyna jako »magicznego « miejsca, w którym zanikają granice, ich Cieszyn jest wspólny a nie polski czy czeski [...]. Wielka polityka, dramaty historii jawią się jak coś obcego, przychodzącego z zewnątrz, jako siła niszcząca harmonię w sielankowej »małej ojczyźnie« kilku narodów"23.

Praca nad scenariuszem Těšínského nieba wymagała zapoznania się z licznymi publikacjami polsko- i czeskojęzycznymi z zakresu historii i etnografii (i to różnie datowanymi), z regionalnym piśmiennictwem literackim (polskim, w tym w opcji zaolziańskiej i czeskim), z lokalnymi podaniami i legendami, także materiałami prasowymi - z wieku XIX i XX (nierzadko $\mathrm{w}$ przedstawieniu przywoływanymi w ich oryginalnym brzmieniu). W spektaklu i programie do przedstawienia wykorzystano cytaty i materiały między innymi z: Dziejów Śląska Austriackiego Franciszka Popiołka, Śląska Gustawa Morcinka, Godek ślaskich Pawła Ondrusza, pracy zbiorowej Płyniesz Olzo... Zarys kultury duchowej ludu cieszyńskiego pod redakcją Karola Daniela Kadłubca i tegoż Uwarunkowań cieszyńskiej kultury ludowej, z albumów: Henryka Wawreczki, Janusza Spyry, Mariusza Makowskiego Těšín - Český Těšin na starých pohlednicích a fotografiích oraz J. Blumenscheina, L. Kysela, K. Stenchlá Tramvaje v Těšině. Dwie publikacje wydają się przy tworzeniu scenariusza Těšínského nieba wiodące i równoważne: polskojęzyczny Śląsk za Olzq Pawła Hulki Laskowskiego (wyd. 1938) i czeskojęzyczne Vlastenecké putování po Slezsku Františka Slámy (wyd. 1886) ${ }^{24}$. „Literackie opracowania dialogów budzą uznanie, piękne są przekłady poetyckie" - reasumowała pracę na poziomie scenariusza krytyk teatralny Irena T. Sławińska ${ }^{25}$.

22 K. Kardyni-Pelikanová: Těšínské niebo - Cieszyńskie nebe, czyli górą bliźnięta (zodiakalne). cyt.wyd.

23 S. Wójcik: Muzyczna podroż do Cieszyna. http://www.pk.org.pl/artykul. php?id=44 (30.01.2015).

24 Postacie dr. Slámy (działacza narodowego, pisarza) i Hulki Laskowskiego wprowadzone zostały wprost w materię scenariusza, a wraz z nimi dokładne cytowania z publikacji ich autorstwa. (Notabene uczoność wywodów obu pisarzy nt. kultury duchowej ludu Śląska Cieszyńskiego raz po raz rozbijana była przez zdroworozsądkowe komentarze słuchaczy, co wskazywało, iż lud śląski miał do siebie duży dystans, co dodatkowo stanowiło źródło komizmu).

25 I. T. Sławińska: Zaczarowanym tramwajem po Cieszynie. „Śląsk” 2004, nr 8, s. 70 . 
Warstwa językowa stanowiła osobną wartość przedstawienia. W spektaklu mówiło się po „po polsku, po czesku, trochę gwarą i [...] po niemiecku”, by odwołać się do słów pieśni Nohavicy, mówiło się także w języku jidysz. Prawdziwy konglomerat językowy, będący wyznacznikiem wielokulturowości prezentowanego miejsca. Co wszak najistotniejsze - wszyscy miejsce owo zasiedlający nawzajem starali się siebie zrozumieć. Bliskość genetyczna języka czeskiego i polskiego sprawia, iż proces wzajemnego porozumiewania się pomiędzy Polakami i Czechami nie napotykał na Śląsku Cieszyńskim na większe przeszkody ${ }^{26}$, aczkolwiek posługiwanie się przez bohaterów Těšínského nieba tzw. wyrazami zdradliwymi ${ }^{27}$ rodziło potknięcia i nieporozumienia, wyzwalało sytuacje konfliktowe, częściej jednak - w myśl przyjętej przez twórców spektaklu nadrzędnej zasady - humorystyczne. I w tym zakresie edukowano się wzajemnie i poszerzano własne kompetencje językowe ${ }^{28}$.

Sceniczną wizualizacją do lata 1920 roku trwającej jedności Cieszyna była makieta tramwaju (linia tramwajowa łączyła dworzec kolejowy, dziś Český Těšín, z Wyższą Bramą, dziś Cieszyn). Podobnie reprezentatywne budowle obu miast w pierwszych sekwencjach spektaklu razem na scenie widzom się prezentujące, bez szczególnego baczenia, po której stronie Olzy są usytuowane $^{29}$. Dopiero ustanowienie linii granicznej przyporządkuje wymienione budowle Cieszynowi i Czeskiemu Cieszynowi. Podział ten obejmie również ludzi tworzących jeszcze do niedawna wspólnotę. Olza (aktorka z długim niebieskim szalem niby rzeki wstęgą) „stanie” pomiędzy nimi i będzie starała się godzić obie strony jako do obu państw przynależna. Jedność miast gra-

26 Co z uznaniem podkreślał dr Sláma: „Lid zdejšsí dobře rozumí česky i polsky”. Renata Putzlacher, Radovan Lipus: Těšínské niebo Cieszyńskie nebe. Scenariusz, s. 30.

27 „Wyrazy zdradliwe” to rodzime i obce jednostki leksykalne, które są w dwu językach formalnie zgodne lub podobne, ale znaczeniowo odrębne. W procesie komunikacji międzyjęzykowej mają wpływ na skuteczność tego procesu, zawierają bowiem niebezpieczeństwo wprowadzenia w błąd, wywołują niespodziewane skutki. Szerzej na ten temat zob. E. Lotko: Zrádná slova v polštině a češtině. Olomouc 1992, Votobia.

28 Przykładowy dialog z użyciem wyrazu zdradliwego: Polka: Jodłeś kiedy cieszyński chlyb?/ Čech: Mmm, mňnam, čerstvý chlebíček.../Polka: Jaki czerstwy! Tyn chlyb je świży, prosto z pieca!/Polak: Czerstwy to po czesku świeży. A po polsku nieświeży i twardy.... Renata Putzlacher, Radovan Lipus: Těšínské niebo Cieszyńskie nebe. Scenariusz, s. 30.

29 Zminiaturyzowane” Wieża Piastowska, Rotunda, Studnia Trzech Braci, kościół NSPJ, teatr gmachy obu Ratuszy, kawiarnia Avion, drukarnia Prochasky, jako makiety osadzone zostały na głowach aktorów. 
nicznych starano się uwydatniać nie tylko poprzez określone zabiegi wizualizacyjne, ale akcentowano ją wyraźnie już od początkowych faz powstawania projektu. Pierwsza próba czytana scenariusza z udziałem zaproszonych gości z obu Cieszynów odbyła się 16 marca 2004 roku w stylowych wnętrzach Café Muzeum w Cieszynie, drugie zaś „urodziny” projektu świętowano 15 maja 2006 roku w Cieszyńskim Ośrodku Kultury - Domu Narodowym. Przedstawienie zagrano pięciokrotnie w cieszyńskim Teatrze im. A. Mickiewicza, zawsze z frekwencyjnym sukcesem, zawsze witane jako „swoje”30, o swojskich tematach traktujące.

Těšinské niebo Cieszyńskie nebe obudowane zostało licznymi działaniami wokółspektaklowymi, manifestowało swą obecność również poza czeskocieszyńskim i cieszyńskimi budynkami teatralnymi. W maju 2005 roku odbyła się emisja radiowa przedstawienia (Radio Ostrawa), zaś we wrześniu 2007 roku telewizyjna. Uroczystym rocznicowym spektaklom towarzyszyły między innymi promocje: płyty CD zawierającej piosenki z przedstawienia, płyty DVD z nagranym spektaklem, książki i mapy „Těšínské niebo Cieszyńskie nebe"31 (widzowie zaopatrzeni w mapę mogli z artystami Td odbyć na zakończenie sezonu teatralnego 2006/2007 spacer uliczkami Czeskiego Cieszyna szlakiem Těšinského nieba). Spektakl posiadał i posiada nadal własną stronę internetową (http://www.tdivadlo.cz/tn/), na której można między innymi zapoznać się z fragmentami scenariusza, recepcją przedstawienia, także bogatym materiałem fotograficznym.

Co niezwykle istotne - przedstawienie przekroczyło granice Śląska Cieszyńskiego. Grane było po wielokroć w Republice Czeskiej (między innymi w Pradze ${ }^{32}$, Ostrawie, Opawie, Hradec Kralové, Brnie, Nowym Jičině), na Słowacji, także w Polsce (między innymi w Łodzi z okazji jubileuszu 55-lecia Teatru Nowego, w Warszawie w Teatrze na Woli w ramach cyklu „A to Polska właśnie", gdzie prezentacji przedstawienia towarzyszyła nocna audycja radiowej "Jedynki" (listopad 2005)). Wszędzie było owacyjnie witane, długo oklaskiwane,

30 Pierwsze dano 4 grudnia 2004 roku, pozostałe - we wrześniu 2005 roku i w maju 2010 roku.

31 Wydanie mapy wydaje się w pełni zasadne, bo - jak zauważył Mariusz Szczygieł - „według piosenek Nohavicy - jak według przewodnika - można zwiedzać oba Cieszyny”. M. Szczygieł: Nohavica dla czechofilów. „Gazeta Wyborcza”, 19-20.11.2005.

32 Spektakl grano w Divadle pod Palmovkou. O jego niewątpliwym sukcesie można przeczytać w: J. Borovička: Inscenace Těšínské nebe prilakala pozornost prazského publika. http://www.tdivadlo.cz/tn/ (25.01.2015). 
nagradzane (w 2004 roku zyskało także miano najlepszego spektaklu IV Festivalu divadel Moravy a Slezska ${ }^{33}$, organizowanego w Czeskim Cieszynie. Jury uzasadniło swój werdykt „wyjątkowością dramaturgiczno-inscenizacyjnego projektu, który powstał w regionie wielokulturowym” i „uwzględnia specyfikę stosunków polsko-czeskich i czesko-polskich"34). Przedstawienie, utrzymujące się na teatralnym afiszu do dnia 18 czerwca 2011 roku, zagrano ogółem 136 razy. Obejrzało je 49055 widzów. Scenariusz Těšínského nieba Cieszyńskiego nebe wraz z fotografiami ze spektaklu i komentarzem doc. Jana Hyvnara z Katedry Wiedzy o Teatrze Uniwersytetu Karola w Pradze opublikowany został w prestiżowym praskim piśmie teatralnym „Disk” (2005, nr 13).

Próby wyjaśnienia fenomenu spektaklu, utrzymującego się w repertuarze Těšínského divadla przez siedem sezonów i odnoszącego sukcesy poza macierzystą sceną, i to zarówno w Republice Czeskiej, jak i w Polsce, także na Słowacji, podjął się Kazimierz Kaszper: „spektakl jest skoncypowany tak, żeby pokazywać pewną rzeczywistość wypraną z jakichkolwiek konfliktów. Tymczasem my, dziennikarze, działacze społeczni, staramy się podkreślać etos mieszkańców tej ziemi określony przez pewną rywalizację. A tu się okazuje, że pozbawienie przedstawienia tego składnika może się nawet publiczności podobać. I to nie tylko naszej, zaolziańskiej, nie tylko czeskiej, gdzie można by się tego spodziewać, ale także i polskiej, która tłumnie przyjeżdżała na kolejne przedstawienia ${ }^{35}$. W świetle powyższej konstatacji kluczem do sukcesu stała się zatem konsekwentna realizacja nadrzędnej zasady przyjętej przez twórców spektaklu.

Tak zamyślony i zrealizowany projekt niewątpliwie współuczestniczył w podejmowanym po 1989 roku procesie formowania odpowiednio wysokiego poziomu zbiorowej tożsamości lokalnej, regionalnej oraz, co wydaje się najistotniejsze, tożsamości euroregionalnej społeczności zamieszkujących oba miasta graniczne i oba przygraniczne obszary. Integrując oba różnojęzyczne zespoły działające w strukturze jednej instytucji oraz obie różnojęzyczne, autonomiczne widownie, a poprzez liczne wystawienia poza macierzystym ośrodkiem teatralnym także Polaków i Czechów, honorował wszak obopólne wstąpienie Polski i Republiki Czeskiej do Unii Europejskiej. Także program do przedstawienia nawiązywał w sposób bardzo wyraźny do tego

33 Festiwal - zgodnie z nazwą - prezentuje najlepsze przedstawienia danego sezonu, powstałe w teatrach regionu: Ostrawie, Opawie, Novym Jičinie, Czeskim Cieszynie.

34 Zob. 4. FDMS zaver Poroty [Protokół obrad jury IV Festivalu divadel Moravy a Slezska], archiwum Těšínského divadla Český Těšín.

35 K. Kaszper: W sobotę pożegnamy „Těšínské niebo”. „Głos Ludu”, 16.06.2011. 
przełomowego dla społeczności pogranicza faktu - na tylnej okładce (projektu Mariana Siedlaczka z Czeskiego Cieszyna) znalazła się modyfikacja podstawowego symbolu Unii Europejskiej - flagi: każda z dwunastu złotych gwiazd rozłożonych w okręgu na chabrowym tle zyskała znaczący „cieszyński” odpowiednik - złocony element biżuterii zwany w Cieszyńskiem hoczkiem, a wchodzący w skład ubioru zamożnych mieszkanek Cieszyna przełomu wieków XIX i XX oraz początków wieku XX (obecnie element stroju cieszyńskiego), natomiast chabrowe tło pierwowzoru zastąpione zostało błękitem nieba nad Cieszynem. Tym samym „zintegrowana” cieszyńska historia miejsca weszła - poprzez teatr - do zintegrowanej historii Europy, wnosząc własne, nader cenne dziedzictwo, motywowane wielokulturowością regionu. Przyjęcie przez realizatorów spektaklu dwujęzycznego, niejako „lustrzanego”, tytułu realizowało w świetle powyższego formułę teatru związanego ściśle $\mathrm{z}$ miejscem i z czasem, w jakim przyszło mu funkcjonować - $\mathrm{z}$ wielokulturowym pograniczem wchodzącym do wspólnoty europejskiej mocą międzykulturowego dialogu $\mathrm{u}^{36}$.

Długa eksploatacja przedstawienia sprawiła, że czas z konstytuującymi go ważnymi wydarzeniami politycznymi następującymi po 15 maja 2004 roku (przede wszystkim wejście w życie Układu z Schengen) i ich pochodną zweryfikował pewne treści dotyczące życia na granicy, część spraw żywotnych wiosną 2004 roku ulegała w miarę upływu kolejnych lat grania spektaklu dezaktualizacji, tak jak chociażby oczywista podczas pracy nad projektem konstatacja reżysera Radovana Lipusa, że: „Cieszyn ma najdziwniejsze na świecie mosty - jednym można wjechać do Polski, drugim wrócić do Czech, na tych przejściach granicznych nie można się spotkać, bo są jednokierunkowe"37, utraciła na aktualności z momentem wprowadzenia w 2011 roku na moście Wolności ruchu dwukierunkowego. Jednocześnie zachował swą żywotność drugi człon wypowiedzi reżysera, iż „Jarek Nohavica sprawił, że [...] w muzyce te mosty zaczęły działać w obie strony"38. Nie ziściło się

36 W odniesieniu do tytułu warto wspomnieć o jeszcze jego dwóch, nader szczególnych, „lokalnych” aspektach - gmach Těšínského divadla posiada obserwatorium astronomiczne pozwalające na obserwacje nad Cieszynami. W sierpniu 2000 roku czeska astronomka Lenka Šarounová odkryła planetoidę (ozn. 2000 PT8), którą nazwała „Těšínsko”.

37 Cyt. za: R. Putzlacher: Pod cieszyńskim niebem... W: R. Putzlacher (red.): Program do przedstawienia Těšinské niebo Cieszyńskie nebe”. Český Těšín 2004.

38 Tamże. 
wprawdzie marzenie twórców spektaklu o przywróceniu linii tramwajowej, łączącej od 1911 do 1921 roku prawobrzeżną i lewobrzeżną część Cieszyna i przebiegającej przez most Przyjaźni, ale to właśnie makieta historycznego tramwaju umiejscowiona została na środku mostu w pamiętną noc z 20 na 21 grudnia roku 2007, w jej wnętrzu włodarze obu miast podpisywali stosowne umowy o współpracy. Trzy lata wcześniej przed tym historycznym wydarzeniem (w listopadzie 2004 roku) sami twórcy przedstawienia makietę tramwaju ustawili na moście Przyjaźni przy okazji „chrztu” w nurtach Olzy płyty $C D$, utrwalającej piosenki ze spektaklu ${ }^{39}$ (nader wymownym było, iż aktu „chrztu” dokonywali pospołu celnicy polscy i czescy w otoczeniu artystów Td i mieszkańców obu Cieszynów) ${ }^{40}$.

Przedstawienie Těšinské niebo Cieszyńskie nebe potwierdziło sprawdzalność tezy, iż pogranicza „z natury coś łączą [...], stanowią dowód na to, że pewnych procesów i zbiorowości społecznych nie da się rozdzielić" ${ }^{41}$. Propagowało ideę „kultury bez granic, w której nie zwycięstwo jednej kultury narodowej nad innymi jest waloryzowane dodatnio, lecz wzajemna [...] synteza"42. Przy czym dodać należy, że przedstawienie, będące artystyczną wizualizacją wspólnoty kulturowej Śląska Cieszyńskiego i wspólnoty dziejów, nie jest w przywołanej perspektywie propozycją repertuarową w dorobku Těšínského divadla osamotnioną. Spektaklem Cieszyńskie nebe poprzedzającym, w którym najdobitniej zobrazowano, że „sens współżycia [na pograniczu - M.P.] polega na [...] wspólnym przeżywaniu świata"43, była Czarna Julka Sceny Polskiej, w reżyserii Janusza Klimszy ${ }^{44}$.

39 Na płycie znalazło się dwadzieścia piosenek J. Nohavicy w nowych aranżacjach T. Kočko, wykonywanych przez samego barda i aktorów obu Scen. Płytę „ze względu na jej bardzo lokalny, cieszyński charakter” za znakomitą wizytówkę miasta - „wspólnego a nie polskiego czy czeskiego" - uznał Sławomir Wójcik. Zob. S. Wójcik: Muzyczna podroż do Cieszyna. cyt.wyd.

40 Na ten temat: M. Boková: Nebe a sny nad Těšinem. http://www.nedelnisvet.cz (21.11.2004).

41 G. Babiński: Pogranicze polsko-ukraińskie. Etniczność, zróżnicowanie religijne, tożsamość. cyt.wyd.

42 K. Kardyni-Pelikanová: Těšínské niebo - Cieszyńskie nebe, czyli góra bliźnięta (zodiakalne). cyt. wyd.

43 Zob. Wypowiedź J.Klimszy w rozmowie z K.Kaszperem: K.Kaszper: Kolonia w środku Europy. „Górnośląski Dariusz Kulturalny” 1994, nr 1/2, s. 26-27.

44 Szerzej na ten temat zob. M. Pindór: Przywracanie Morcinka zaolziańskiej społeczności... (O realizacjach prozy Morcinka w Scenie Polskiej Těšínského divadla). 
Těšínské divadlo - jesienią 2015 roku obchodzące siedemdziesięciolecie swego istnienia, od 64 lat dysponujące dwiema współistniejącymi obok siebie Scenami, postrzeganymi przez Jacka Balucha „właśnie z racji owego sąsiedztwa" jako "teatry narodowe" 45 - jest instytucją jak najbardziej predestynowaną do podejmowania międzykulturowych praktyk artystycznych z wpisanymi weń celami edukacyjnymi, takimi jak: „doprowadzenie do wzajemnego poznania i zrozumienia odmienności, kształtowanie pozytywnych wzajemnych odniesień, poszukiwanie wspólnych korzeni kulturowych z jednoczesnym zakorzenieniem w »ojczyźnie prywatnej «"46. Wszystkie te, wymienione za Jerzym Nikitorowiczem, cele edukacyjne, $\mathrm{w}$ tym sensu stricte wchodzące w zakres edukacji międzykulturowej, takie jak kształtowanie otwartości, wyrzekanie się „poczucia wyższości kulturowej na rzecz [...] dbałości o wspólny spadek dziedzictwa kulturowego"47, w tym „kultury pogranicza”48 (zwłaszcza w obliczu wejścia w grupę państw Unii Europejskiej i czasów naznaczonych procesami globalizacji) przywołany w niniejszym szkicu projekt dramaturgiczno-inscenizacyjny Sceny Polskiej i České scény Těšínského divadla spełniał. Świadczą o tym głosy krytyki - polskiej, czeskiej, jak i reakcja publiczności - zarówno polsko-, jak i czeskojęzycznej pospołu na widowni teatru przy ul. Ostrawskiej w Czeskim Cieszynie zasiadającej. Wykrystalizowanie się przestrzeni współbycia widowni dwu kultur, poznanie nastrojów zróżnicowanej językowo publiczności we wzajemnym kontakcie, to wartość nie do przecenienia.

Za Jaromírem Nohavicą należy powtórzyć: Nebe je tu, nebe je tam, nebe je všude, kde jsme my ${ }^{49}$ / Niebo jest tu, niebo jest tam, niebo jest wszędzie, tam gdzie my - wspólnotą dziejów i czasów najnowszych naznaczeni - mieszkańcy wielokulturowego pogranicza w Cieszyńskiem, mocą procesu dialogu kultur w jedność skonsolidowani.

W: K. Heska-Kwaśniewicz, J. Lyszczyna (red.): Gustaw Mocinek - w 120-lecie urodzin. Katowice 2012, Wydawnictwo Uniwersytetu Śląskiego, s. 226-241.

45 Zob. K. Olbrycht, M. Pindór (red.): Národní divadla. Tradice a současnost/ Teatry narodowe. Tradycja i wspótczesność. Cieszyn 2003, Uniwersytet Śląski - Filia w Cieszynie, s. 7.

46 J. Nikitorowicz, Pogranicze, tożsamość, edukacja międzykulturowa. Białystok 2001, Wydawnictwo Uniwersyteckie „Trans Humana”, s. 8.

47 Tamże, s. 10.

48 Tamże, s. 13.

49 J. Nohavica: Nebe je tu. Putzlacher,R., Lipus R.: Těšínské niebo Cieszyńskie nebe. Scenariusz. cyt. wyd. s. 3. 


\section{Bibliografia}

Babiński G.: Pogranicze polsko-ukraińskie. Etniczność, zróżnicowanie religijne, tożsamość. Kraków 1997, „Nomos”.

Boková M.: Nebe a sny nad Těšínem. http://www.nedelnisvet.cz (21.11.2004). Borovička J.: Inscenace Těšínské nebe přilakala pozornost prazského publika. http://www.tdivadlo.cz/tn/ (25.01.2015).

FDMS závěr Poroty [Protokół obrad jury IV Festivalu divadel Moravy a Slezska] archiwum Těšínského divadla Český Těšín.

Heclová I., Jarnotová A., Wania J. (red.): Nabídka představení Těšinského divadla v Českém Těšině. Sezona 2003/2004. Repertuar Sceny Polskiej Teatru Cieszyńskiego w sezonie 2003/2004. Český Těšín 2003.

http://www.tdivadlo.cz/tn/ (30.01.2015).

Kardyni-Pelikanová K.: Těšínské niebo - Cieszyńskie nebe, czyli górą bliźnięta (zodiakalne). „Zwrot” 2006, nr 1.

Kaszper K.: Kolonia w środku Europy. „Górnośląski Dariusz Kulturalny” 1994, nr 1-2.

Kaszper K: W sobotę pożegnamy „Těšínské niebo”. „Głos Ludu”, 16.06.2011.

Lewowicki T.: W poszukiwaniu modelu edukacji międzykulturowej. W: T. Lewowicki, J. Nikitorowicz, T. Pilch, S. Tomiuk (red.): Edukacja wobec ładu globalnego. Warszawa 2002, Wyższa Szkoła Pedagogiczna ZNP, Instytut Pedagogiki Społecznej i Resocjalizacji UW, Wydawnictwo Akademickie „Żak”.

Lotko E.: Zrádná slova v polštině a češtině. Olomouc 1992, Votobia.

Nikitorowicz J., Pogranicze, tożsamość, edukacja międzykulturowa. Białystok 2001, Wydawnictwo Uniwersyteckie „Trans Humana”.

Nikitorowicz, T. Pilch, S. Tomiuk (red.): Edukacja wobec ładu globalnego. Warszawa 2002, Wyższa Szkoła Pedagogiczna ZNP, Instytut Pedagogiki Społecznej i Resocjalizacji UW, Wydawnictwo Akademickie „Żak”.

Olbrycht K., Pindór M. (red.): Národní divadla. Tradice a současnost/ Teatry narodowe. Tradycja i wspótczesność. Cieszyn 2003, UŚ - Filia w Cieszynie.

Pająk E.: Edukacja międzykulturowa w szkole na przyktadzie programu Coverdell World Wise Schools (CWWS) - wyzwania wielokulturowości w Stanach Zjednoczonych i Unii Europejskiej. W: A. Szerląg (red.): Wielokulturowość - międzykulturowość obszarami edukacyjnych odniesień. Kraków 2005, Uniwersytet Wrocławski, Oficyna Wydawnicza „Impuls”. 
Pergelová K.: Těšínské niebo pod Vyšehradským nebem. http://folktime.cz (24.08.2005).

Pindór M.: Polsko-czeskie i polsko-słowackie kontakty teatralne. Cieszyn Český Těšin 1945-1999. Katowice 2006, Polska Akademia Nauk Oddział w Katowicach, Komisja ds. Stosunków Polsko-Czeskich i Polsko-Słowackich, Wydawnictwo Naukowe i Artystyczne „Gnome”.

Pindór M.: Przywracanie Morcinka zaolziańskiej spoteczności... (O realizacjach prozy Morcinka w Scenie Polskiej Těšínského divadla). W: K. Heska-Kwaśniewicz, J. Lyszczyna (red.): Gustaw Mocinek - w 120-lecie urodzin. Katowice 2012, Wydawnictwo Uniwersytetu Śląskiego.

Putzlacher R. (red.): Program do przedstawienia Těšínské niebo Cieszyńskie nebe". Český Těšín 2004.

Putzlacher R., Lipus R.: Těšínské niebo Cieszyńskie nebe. Scenariusz, archiwum Těšínského divadla, Český Těšín.

Sławińska I. T.: Zaczarowanym tramwajem po Cieszynie. „Śląsk” 2004, nr 8. Szczygieł M.: Nohavica dla czechofilów. „Gazeta Wyborcza”, 19-20.11.2005. Wójcik S.: Muzyczna podroż do Cieszyna. http://www.pk.org.pl/artykul. php?id=44 (30.01.2015).

\section{Coexistence space. Těšínské niebo Cieszyńskie nebe [Cieszyn Sky] of the Cieszyn Theatre in Czech Cieszyn as intercultural narration about multiculturalism of the town(s)}

\section{Summary}

What was subjected to analysis in the presented study is the bilingual stage project of the Polish Scene and the Czech Scene of the Cieszyn Theatre in Czech Cieszyn entitled Těšínské niebo Cieszyńskie nebe /Cieszyn Skies/ (first staged on $15^{\text {th }}$ May 2004). In compliance with the intentions of the undertakers: Jaromír Nohavica, Renata Putzlacher, Radovan Lipus, Tomaš Kočko, this musical "sentimental tramway trip" through ages in the multicultural region and town was "an attempt at viewing the area of Cieszyn through the past years and events - an attempt full of nostalgia and humour as well as references to real and mythical figures associated with this region" ${ }^{10}$. This was carried out according to the supe-

50 Zob. I. Heclová, A. Jarnotová, J. Wania (red.): Nabídka představení Těšínského 
rior principle, applied by the authors of the project and inspired by the idea of the Euroregion, of exposing what has been linking the borderland community (and results in a platform of common values) and not what has been dividing it. The search for common elements of culture and historical similarities has turned out to be compliant with the assumptions of intercultural education. The applied option of viewing the Polish-Czech borderland history and the vision of coexistence of both nationalities in the area of Cieszyn have been also determined by joining the structures of the European Union (the opening took place on $15^{\text {th }}$ May 2004). It was from this perspective that the consecutive sequences of the spectacle were constructed, unveiling the concept of the borderland man as a more complete person - spiritually enriched with the dissimilarity of the other. The spectacle has contributed to the process (started in 1989) of forming appropriately high collective local, regional and Euroregional awareness of the community inhabiting both borderland towns and regions.

Słowa kluczowe: borderland, Cieszyn - Czech Cieszyn, multiculturalism, interculturalism, identity, theatre, Polish Scene and the Czech Scene of the Theatre in Czech Cieszyn

Translated by Maria Stec

divadla v Českém Těšínè. Sezona 2003/2004. Repertuar Sceny Polskiej Teatru Cieszyńskiego w sezonie 2003/2004. Český Těšín 2003. 

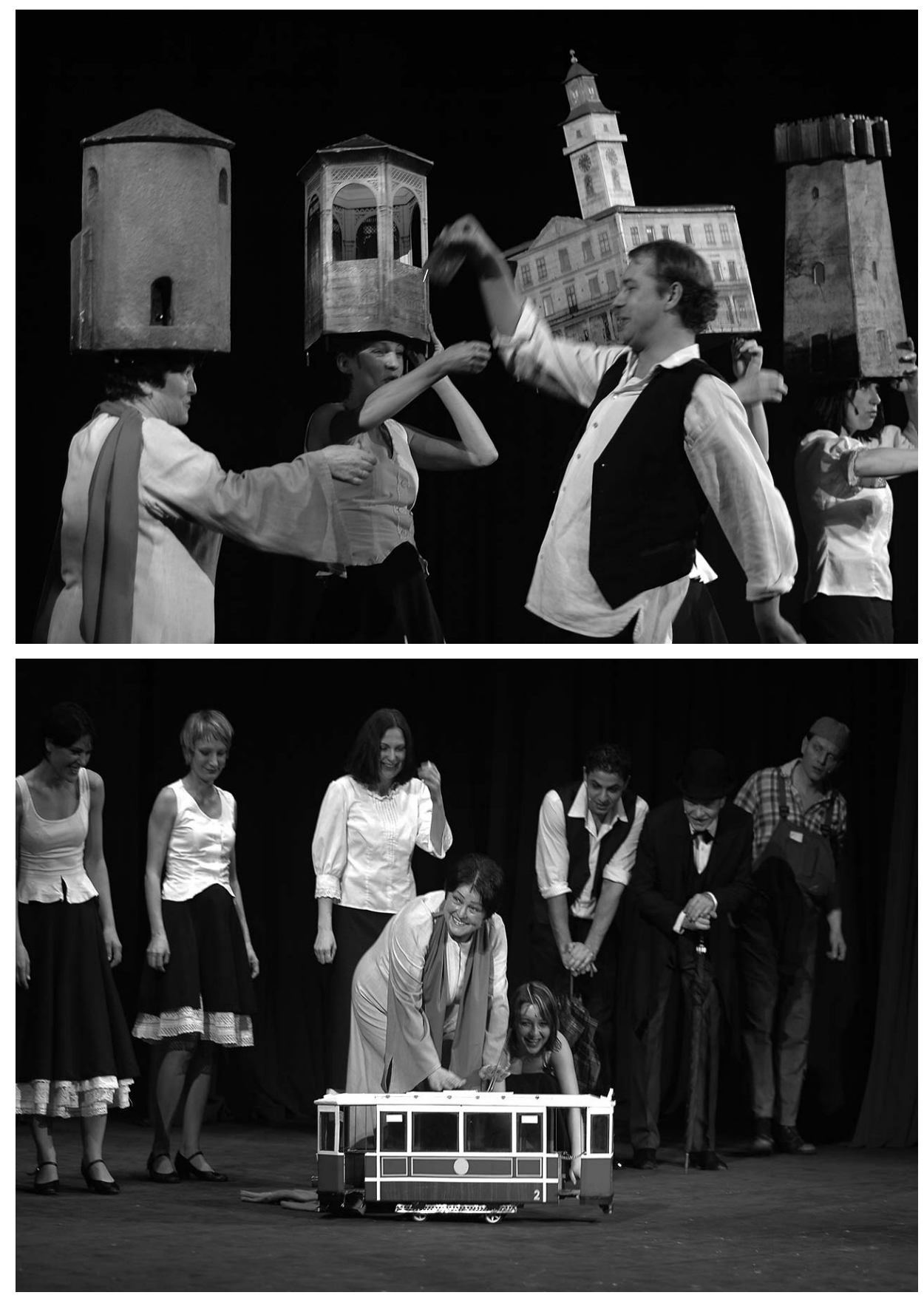